\title{
CONSUMER CONFIDENGE FROM CLUJ-NAPOCA METROPOLITAN AREA, IN THE FOOD LABELING SYSTEM
}

\author{
Ioana Ancuța Iancu ${ }^{1 *}$ and Alexandru-Mircea Nedelea ${ }^{2}$ \\ 1) Technical University of Cluj-Napoca, Cluj-Napoca, România \\ 2) Ștefan cel Mare University, Suceava, România
}

Please cite this article as:

Iancu' I.A. and Nedelea, A.M., 2018. Consumer Confidence from Cluj-Napoca Metropolitan Area, in the Food Labeling System. Amfiteatru Economic,

\section{Article History}

Received: 29 September 2017

Revised: 15 October 2017

Accepted: 10 November 2017 20(47), pp. 116-133.

\begin{abstract}
In order to discover the aspects that influence the consumer level of confidence (from ClujNapoca metropolitan area), regarding the information on the food label and their reading frequency a study based on a questionnaire was made. This was promoted online, especially on Facebook and was filled in by 392 persons. Besides the descriptive analysis meant to offer us an overview of the aspects that influence the consumer level of confidence regarding the information on the food label, the authors have proposed to observe the level of association and test some hypotheses, which are linked to the importance of some elements (sex, age, education, family income, buying food for children under 5 and over 6 years old, smokers, athletes, the perception of the correctness of information on the label, food poisoning, country of origin and the benefits of technology in food sector).

The results indicate a decrease in the level of confidence of Romanian consumers in the information on the food label, while the age, the number of years spent on formal study, increased revenue and shopping of products for children under the age of 5 influence the frequency of label reading. On the other side, women grant a higher importance to the information that is mandatory, by law, to be included on the label, than men. This study shows the importance of improving the trust of consumers in the food labelling system by increasing the frequency of reading. We underline that information of consumers can't be successfully achieved if they don't read or trust the information found on the labels.
\end{abstract}

Keywords: consumers' information, labels, the frequency of label reading, trust, food, adjusted residual values, $\chi^{2}$ test.

\section{JEL Classification: M31.}

*Corresponding author, Ioana Ancuța Iancu - anca.iancu@enm.utcluj.ro 


\section{Introduction}

Within the last years we have noticed that a growing importance to food labels is granted. These represent the most important instrument for both the consumer and the producer. Consumers have become more interested in the quality of the products they feed on (Caswell and Joseph, 2008), the processes used to create them (Harper et al., 2007), the nutritive value of the food they are consuming (Gracia and Magistris, 2016), the relation between obesity and food (World Health Organization, 2003; 2011) and the reduction of food waste at global level (Stenmarck et al. 2016). On the other side the producers, sellers, distributors and importers may use food labels for a better communication with the customers (Zadek, Lingayah și Forstater, 1998), to create competitive advantages (Gracia and Magistris, 2016), to differentiate as brand from their competitors, aspect that might influence their loyalty (Liljander, Polsa and van Riel, 2009) and to signal a superior quality (McCluskey and Loureiro, 2003).

If we follow food labelling globally we notice that there are countries where nutritional information is mandatory to be written (United States (U.S.), Canada, Mexico, Argentina, Brazil, Chile, Columbia, Ecuador, Paraguay, Uruguay, European Union (EU), Russia, Israel, Members of the Golf Cooperation Council, Nigeria, India, Hong Kong, China, Japan, South Korea, Malaysia, Taiwan, Thailand, Philippines, Indonesia, Vietnam, Australia and New Zeeland) and countries where this is voluntary (Venezuela, Turkey, Switzerland, Morocco, Lebanon, Jordan, Singapore, Brunei, Myanmar, Vietnam, Kenya, Mauritius and South Africa) (The European Food Information Council - EUFIC, 2017).

During the last decades there were a series of problems from the point of view of food safety. Starting from the scandal of the growth hormones for cows in 1985 (Brand and Ellerton, 1989), the mad cow disease scandal in England, 1989 (Cleeland, 2009), the Nitrofen herbicide scandal in 2002 (GAIN Report, 2002) and many others imposed the introduction of a common law in the entire European space. On the $25^{\text {th }}$ of October 2011, the European Parliament and the European Council approved regulation 1169/2011 related to customer information regarding food products (Euro Commerce \& Food Drink Europe, 2013). Although the regulation adopted states that certain information is mandatory in all member states, the companies that sell products can add additional information on the label (EUFIC, 2017). Precisely these scandals have reduced consumer confidence in food safety.

Roosen (2003) shows that consumer trust can be restored through efficient communication about the food attributes. Even if the consumer information about food is correct, there is the issue of trust and interest shown by the consumer (basically the frequency of reading information on the label). But correct consumer information cannot be achieved if they are unaware of the importance of reading information on the label. There are studies showing that the frequency of reading information on the label is related to the lack of consumer confidence in the food system (Moorman's, 1996; Moorman, Lipinski și Savur, 1998). Starting from this idea, the aim of our work is to provide an overview of consumer confidence in the metropolitan area of Cluj-Napoca in the food labelling system. Thus, the objectives of our study are:

- $\mathrm{O}_{1}$ - investigating the link between certain socio-economic factors and the frequency of reading information on the label;

- $\mathrm{O}_{2}$ - the perception of the correctness of information on the label;

- $\mathrm{O}_{3}$ - the benefits brought by technology in food industry. 
Even if there are regulations at national, regional and European level, the problem is how they are interpreted by Romanian customers. Thus, our pilot study developed around the degree of confidence granted by the customers in the metropolitan area of Cluj-Napoca, as an attraction pole for population, respectively of the investments, to the information found on the label in 2017, therefore including the frequency of reading the information on the label. The results of this study are useful to companies which use labels and food safety institutions, which, through specially created programs, can improve reading frequency and confidence in information on the label. This way, food safety is increased by proper food consumption. Our research will be expanded at national level so it can provide an overview on the importance of reading the labels, as well as the possible differences between the regions of the country.

Our study starts from the idea that correct information can't be achieved if consumers are unaware of the importance of reading the information on the label. The study continues with the review of the literature, research methodology, results and discussions, respectively, the study's conclusions. The review of literature shows that there are studies showing the influence of certain elements on the level of consumer confidence in labels (sex, age, education, income, smokers or athletes, perception of the correctness of information on the label, food poisoning, country of origin, the benefits brought by technology in food industry). To reach the study objectives, a pilot exploratory research was carried out. The questionnaire results, interpreted by the SPSS 21 program, indicate a confidence decrease of the Romanian consumers in the information on the food labels, and the age, the number of years spent in formal education, the high income and the purchase of food for children under 5 years influence the reading frequency of the information on the label. Finally, conclusions, limits and future research are presented.

\section{Literature review}

Labels are hard to decipher by the consumer without serious knowledge of the food industry. Regardless whether we talk about the way the ingredients are stated or how small the characters used are, labels are difficult to understand. Consumers evaluate positively the existence of the label and nutritional table on the package (Alsaddah, 2014), however the level of confidence in the information written on the label id differs from one case to the other. Confidence increases with the high number of positive events, but it decreases rapidly due to a small number of negative events (Liakopoulos and Schroeder, 2003).

EU regulation no 1169/2011 of the European Parliament and the European Council introduces the obligation to specify the following information: "name of the food product, list of ingredients, any ingredient or any technological adjuvant that might cause allergies or intolerance, used in the production or preparation of a food product and is still present in the finished product, even in a modified form, the quantity of certain ingredients or categories of ingredients, net quantity of food product, minimum validity date or expiration date, special storage conditions and/or conditions of use, name or commercial name and address of the food sector operator, country of origin or place of provenance, usage instructions, if their omission would harden the proper use of the food product and a nutritional statement".

Within this study, we will use the concept of confidence from the perspective of the researchers Lewis and Weigert (1985), that highlight the fact that confidence is a social 
concept that can be strengthened or deteriorated through social interactions. Molleing (2006) shows that the cognitive and emotional basis of confidence are interconnected and support each other, but at individual level these rely on the different social situations of the person studied (Lewis and Weigert, 1985).

\subsection{Socio-economic factors and frequency of reading information found on the label}

Research in this field shows that confidence in the entire food system is influenced by the interaction between consumers and the information found on the label (Garretson \& Burton, 2000; Poortinga \& Pidgeon, 2004; Bildtgard, 2008; Batrinou, Spiliotis and Sakellaris, 2008). Ekici (2004), FSANZ (2008), Meyer et al., (2012), Tonkin et al. (2016), show that different demographic features, food shopping location (supermarket, farmer's market), presence of certain diet particularities (allergies), gender, age, education and income are elements that influence confidence in the information found on the label.

Taylor et al. (2012) shows that the gender (women), age (over 45) and income (30000\$$60000 \$$ ) influences the level of importance assigned to safety and confidence in the quality of food. The same authors also show that those from advantaged backgrounds consider twice as important understanding the information on food labels than those from less advantaged environments. The status of smoker or athlete (Satia, Galanko and Neuhouser, 2005), the benefits of technological innovation in the food sector (Worsley, 2003) are other factors influencing the frequency of reading information on the label. Studies show that the frequency of food labels is correlated with the negative attitudes of some consumers (Kristal et al., 1998), the lack of confidence in label information (Soo-Jiuan and Khai-Ling, 2007) and a disregard for the importance of this information (Smith, Taylor and Stephen, 2000).

\subsection{Perception of the correctness of information on the label}

Soo-Jiuan and Khai-Ling (2007) show that the lack of trust in the information found on the labels can lead to the decrease of the number of consumers reading them. Numerous mass media scandals related to the inferior quality of the products sold in Romania compared to the ones in the EU (with the same name), lead to a lack of confidence in the information found on the label (Scărişoreanu, 2016). On the other hand, not reading the food labels is one of the most common reasons for food poisoning (Agri-Food and Veterinary Authority, 2015).

At global level, the studies consulted (table no. 1) show that the persons who live in Australia and New Zeeland have a higher degree of confidence in the information found on the label than the persons that live in the European Union (EU). Same studies show that many consumers don't understand the labels (Sweden) or they don't trust them (Thailand). At EU level, it seems that the highest degree of confidence in the information on the label is granted by Italians, Slovaks and Portuguese while at the opposite pole are the Dutch, Germans and Slovenians (figure no. 1). Romania is in the middle, exactly at the EU average 12 , being rather in-between the European optimists regarding confidence in the information written on the label of food products. 
Table no. 1: Consumer trust in the information on the label

\begin{tabular}{|c|c|c|c|c|}
\hline Authors & $\begin{array}{c}\text { Country of } \\
\text { the study }\end{array}$ & \begin{tabular}{|c|}
$\begin{array}{c}\text { Number of people } \\
\text { questioned }\end{array}$ \\
\end{tabular} & $\begin{array}{c}\begin{array}{c}\text { Type of } \\
\text { investigation }\end{array} \\
\end{array}$ & $\begin{array}{c}\begin{array}{c}\text { Consumer trust in the information on } \\
\text { the label }\end{array} \\
\end{array}$ \\
\hline $\begin{array}{l}\text { Riley at al., } \\
2016\end{array}$ & Australia & 3005 & Questionnaire & $\begin{array}{l}72.5 \% \text { have total or partial confidence } \\
\text { in the information on the label. }\end{array}$ \\
\hline $\begin{array}{c}\text { Gordon et al., } \\
2009 \\
\end{array}$ & New Zeeland & 1525 & Questionnaire & $\begin{array}{l}69 \% \text { have total or partial confidence in } \\
\text { the information on the label. }\end{array}$ \\
\hline \begin{tabular}{|c|} 
Wongprawmas \\
\& Canavari, \\
2015 \\
\end{tabular} & Thailand & 345 & Questionnaire & $\begin{array}{l}\text { Low trust in mandatory legal } \\
\text { regulations. }\end{array}$ \\
\hline $\begin{array}{l}\text { Bosman et al., } \\
2014\end{array}$ & South Africa & 1997 & Questionnaire & Average confidence level. \\
\hline Buzby \& Ready & USA & 1069 & Questionnaire & $\begin{array}{l}55,9 \% \text { have total or partial confidence } \\
\text { in the information on the label. }\end{array}$ \\
\hline $\begin{array}{l}\text { Svederberg \& } \\
\text { Wendin, } 2011\end{array}$ & Sweden & 30 & Interview & $\begin{array}{l}\text { Most consumers trust the information } \\
\text { on the label, although many do not fully } \\
\text { understand the message. }\end{array}$ \\
\hline \multirow{3}{*}{$\begin{array}{c}\text { Ipsos \& } \\
\text { London } \\
\text { Economics, } \\
2013\end{array}$} & $\mathrm{EU} 27+\mathrm{NO}^{*}$ & \multirow{3}{*}{19260} & \multirow{3}{*}{ Interview } & $\begin{array}{l}58 \% \text { trust, } 32 \% \text { do not trust the } \\
\text { information found on the label. }\end{array}$ \\
\hline & EU $15^{* *}$ & & & $\begin{array}{l}57 \% \text { trust, } 32 \% \text { do not trust the } \\
\text { information found on the label. }\end{array}$ \\
\hline & EU $12^{* * * *}$ & & & $\begin{array}{l}61 \% \text { trust, } 30 \% \text { do not trust the } \\
\text { information found on the label. }\end{array}$ \\
\hline
\end{tabular}

*25 EU countries and Norway - except Malta and Cyprus

** countries that joined EU before 1 May 2014

**** countries that joined EU after 1 May 2014

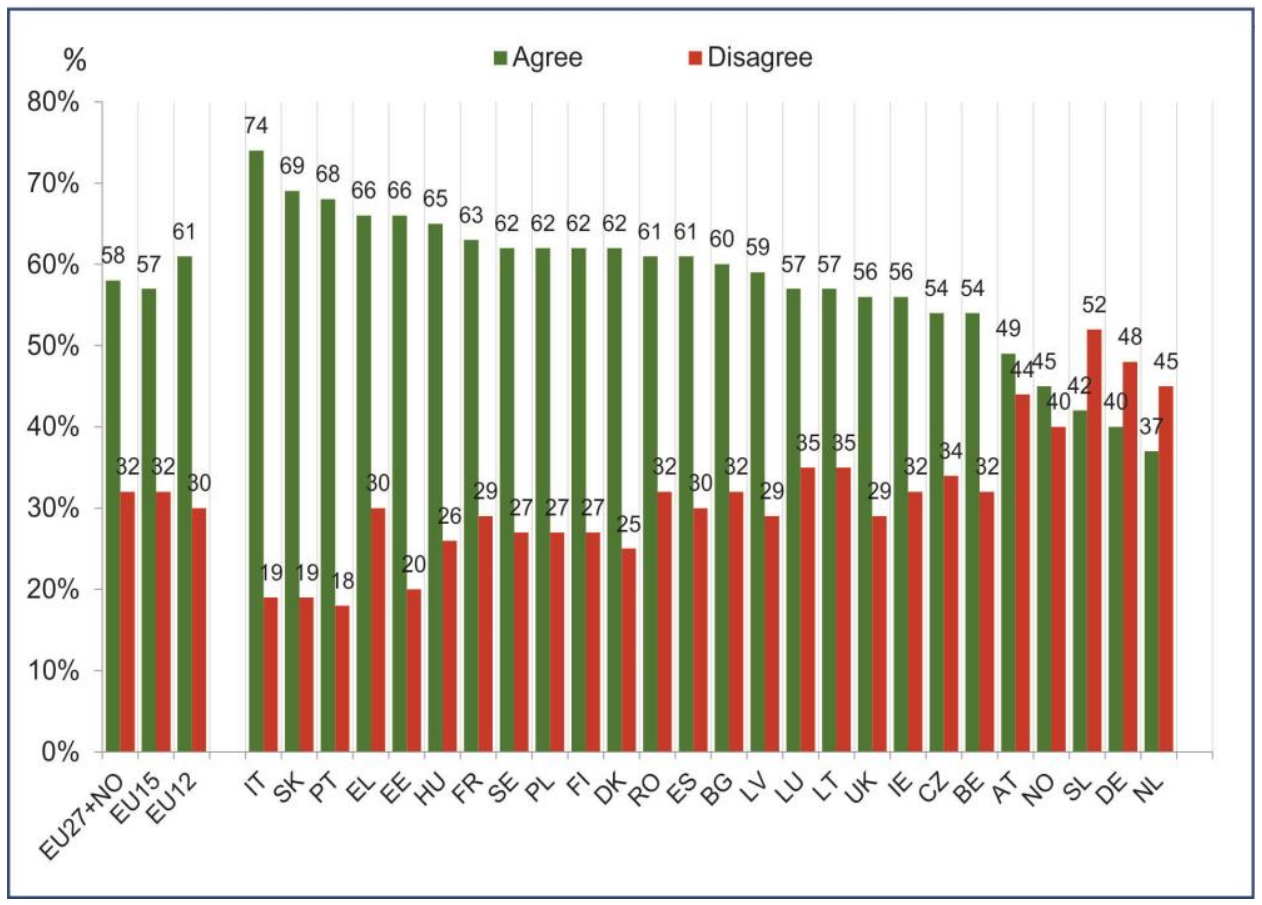

Figure no. 1: Level of confidence in information on labels (EU + Norway)

Source: Ipsos \& London Economics, 2013 


\section{Research methodology}

In order to discover the aspects that influence the consumer level of confidence regarding the information on the food label, a research based on a questionnaire was made. The theoretical foundation of the research was done through activities of collection, analysis and sorting of the information from the specialty literature based on their relevance for our study.

The questionnaire was drawn up by the authors after studying the content of the investigations used in other similar researches and the operationalization of the main concepts that are the base of the study and the formulation of the investigation interrogations. The questionnaire was promoted online, on social media, especially on Facebook. Here the features of the respondents were selected: persons over 18 years old, regardless of the gender, from Cluj-Napoca or the surrounding area (an area of $15 \mathrm{~km}$ around the city was selected). The tax paid for questionnaire promotion was $100 \mathrm{RON}$ (approx. 23 euro) for 14 days (5-19 August 2017). The number of persons who received our questionnaires on their Facebook page was 8320 and was shared by other 141 persons. Thus the response rate was $4.71 \%$. In order to determine the sample, the level of confidence was considered $95 \%$ and the confidence interval $+/-5 \%$. The population studied is the one of Cluj-Napoca metropolitan area.

The questionnaire was created so that it responds to the study objectives:

- a filter question related to the reading of the information on the label. The ones that responded that they never read the information on the label (12 persons), were asked to answer only the questions related to personal, demographic and socio-economic aspects. Their answers are of interest in order to find out which are the features of the ones that do not read the label. The rest, 380 persons, were asked to answer to all the questions in the questionnaire;

- personal, demographic, social and economic aspects of the respondents were deducted based on the answers related to gender, age, own perception of weight, level of education, income category (per family), if the respondent smokes or not, if he does sport, number of children under 5 years for which he/she buys food and the number of children between 6-18 years for which he/she buys food;

- the level of consumer confidence in the information on food labels was done based on the answers to the questions: have you ever suffered from food poisoning (due to a product bought from the store)?, most often you buy local food, food produced in EU or in other countries outside EU, do you consider that the information on the label is real?, do you consider the innovations in the food industry beneficial?, how do you consider food products that are sold in Romania compared to the ones sold in EU?

Questionnaire analysis was done using SPSS 21. Beside the descriptive analysis meant to offer an overview over the aspects that influence the consumer's level of confidence in the information on food label, the authors proposed to observe the level of association between the confidence in labelling and the frequency of reading the information and certain demographic and socio-economic features.

Table no. 2 shows the characteristics of our study respondents. Out of the 392 persons that filled in the questionnaire, 12 persons $(3.06 \%)$ never read the label, women read the labels more frequent than men, the average age of persons who never read the labels is bigger 
than the persons who read rarely at least and university graduates read the labels most often.

Table no. 2: Characteristics of the respondents

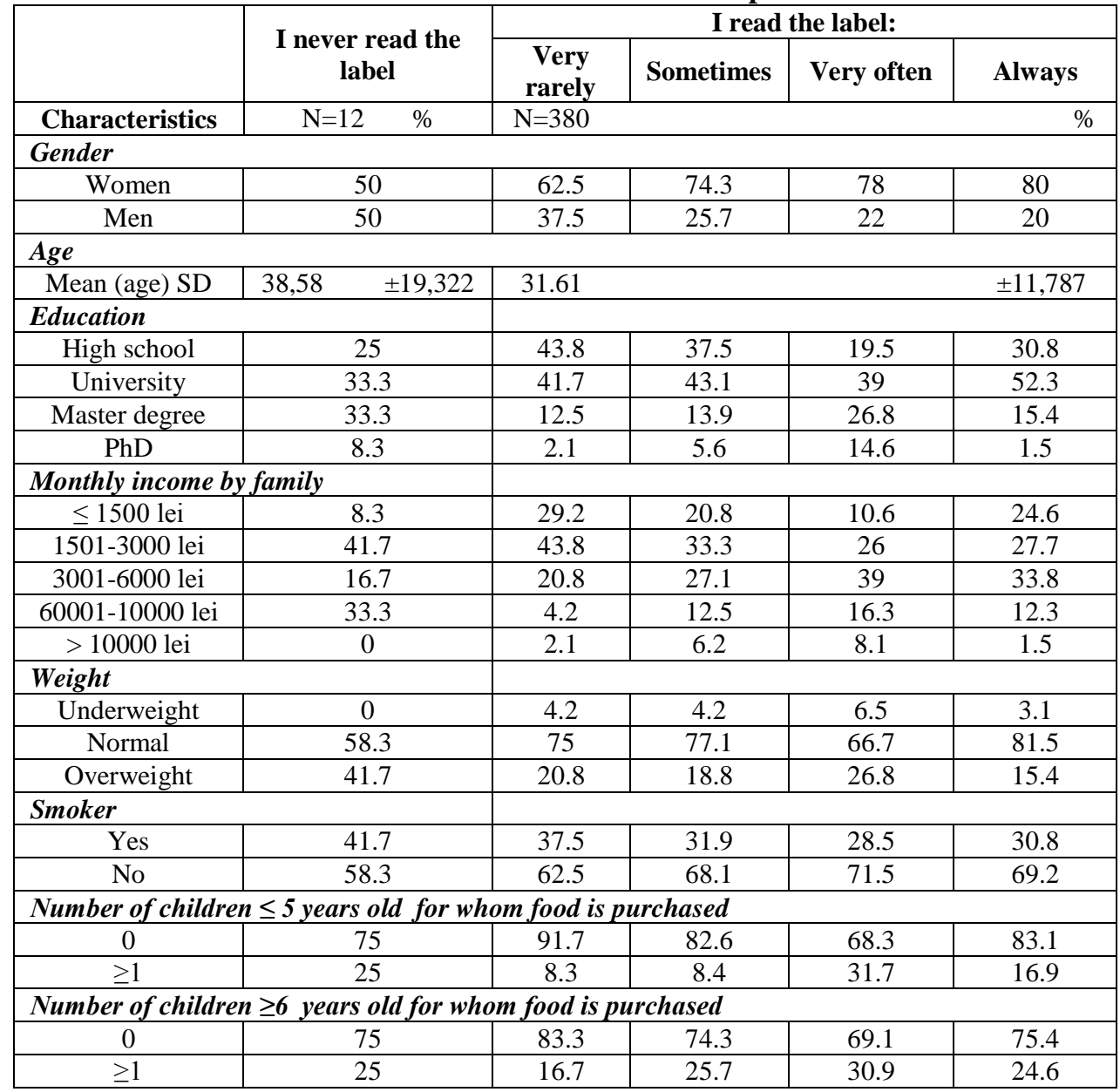

The first objective of our study (investigating the link between certain cultural and socioeconomic factors and the frequency of reading information on the label), was made by testing the hypotheses:

$\mathrm{H}_{1}$ - The mandatory information included on food label is perceived as more important by women than by men (using (Exploratory Factorial Analysis).

$\mathrm{H}_{2}$ - Persons that buy food for children under the age of 5 read in a higher proportion the information on the label than the ones that buy products for children between the ages of 6-18. 
We also testing the link between age, education, income and frequency of reading the information found on the label (the methods used are the analysis of adjusted residual values and $\chi^{2}$ tests).

For the first hypothesis $\left(\mathrm{H}_{1}\right)$, the answers linked with the importance of information mandatory included on food labels, has been subjected to some tests. For the consistency test, the authors used the Cronbach alpha $(\alpha)$ coefficient $(\alpha=0.821$, so $\alpha>0.7)$, the KaiserMeyer-Olkin Measure correlation (KMO) and the Bartlett's test of sphericity (table no. 3 ) (Dabija and Băbuţ, 2013). The literature suggests a good adequacy of the sample if the KMO value is $>0.5$ and the factorial analysis can be continued if KMO>0.7 (Hair et al., 1995). All of these tests indicate a good level of data consistency.

Table no. 3: KMO and Bartlett's Test

\begin{tabular}{|l|c|c|}
\hline \multicolumn{2}{|c|}{ Kaiser-Meyer-Olkin Measure of Sampling Adequacy } & .812 \\
\hline \multirow{2}{*}{ Bartlett's Test of Sphericity } & Approx. Chi-Square & 1129.264 \\
\cline { 2 - 3 } & $\mathrm{df}$ & 45 \\
\cline { 2 - 3 } & Sig. & .000 \\
\hline
\end{tabular}

Out of the initial 11 items, the product name didn't reach the minimum threshold of extraction (0.500), and as a result, it was eliminated. For the other factors we present these values below (table no. 4):

Table no. 4: Values for principal components, data that are mandatory included on the label

\begin{tabular}{|l|c|c|}
\hline & Initial & Extraction \\
\hline List of ingredients & 1.000 & .769 \\
\hline $\begin{array}{l}\text { Any ingredient or any technological adjuvant that might cause allergies } \\
\text { or intolerance }\end{array}$ & 1.000 & .546 \\
\hline The quantity of certain ingredients or categories of ingredients & 1.000 & .701 \\
\hline Net quantity of food product & 1.000 & .539 \\
\hline Minimum validity date or expiration date & 1.000 & .756 \\
\hline Special storage conditions and/or conditions of use & 1.000 & .696 \\
\hline Name and address of the food sector operator & 1.000 & .587 \\
\hline Country of origin or place of provenance & 1.000 & .576 \\
\hline Usage instructions & 1.000 & .506 \\
\hline Packaging is recyclable & 1.000 & .515 \\
\hline
\end{tabular}

Note: Extraction Method: Principal Component Analysis

Source: EU Regulation no. 1169/2011

This type of analysis was preferred because the initial starting dates are associated in a medium-high manner and the principal component method allows us to reduce dimensions with a minimal loss of information (Cramer and Howitt, 2010).

- as a second objective, the perceived correctness of information on food labels was done based on the answers to the questions: do you consider that the information on the label is real?, have you ever suffered from food poisoning (due to a product bought from the store)?, most often do you buy local food, food produced in EU or in other countries outside EU, how do you consider food products that are sold in Romania compared to the ones sold in EU? 
- the last objective, the perception of technological benefits in the food sector, was achieved using crosstabs method, and by calculating the residual value and Chi Square tests we studied the link between them (of the benefits) and the age and income.

\section{Results and discussions}

\subsection{Socio-economic factors and frequency of reading information on the label}

The study of the literature (Ekici, 2004; FSANZ, 2008; Meyer et al., 2012; Taylor et al., 2012; Tonkin et al., 2016) shows that the different characteristics such as: the place of food purchase (supermarket, market), the presence of specific dietary requirements (allergy), gender, age, education and income are factors that influence confidence in the information found on labels.

\section{- Gender}

The results from table no 2 show that men are less interested to read the information on the label, $37.5 \%$ that declare to read it rarely, $25.7 \%$ sometimes, $22 \%$ very often and only $20 \%$ always. The results are not different from the ones of other studies that show that women read the labels in a higher proportion than men (Ekici, 2004; Peters-Texeira and Badrie, 2005; Rasberry et al., 2007; FSANZ, 2008; Food Safety, 2009; Taylor et al. 2012; Meyer et al., 2012; Tonkin et al., 2016).

For $\mathrm{H}_{1}$ (The mandatory information included on food label is perceived as more important by women than by men,) we have run initially the procedure of Exploratory Factorial Analysis (EFA) for the 11 items that made up the mandatory information included on food label.

After running the EFA procedure - the method of the principal components, 3 factors with a different percentage in the explanation of the variance result (table no. 5), highlighted by the Varimax rotation method. First general factor explains approximately $40 \%$ of the variance and includes all 10 items, with factors load between 0.448 and 0.713 (table no. 6). Other two factors explain each approximately $11 \%$ of the variance and are determined by items such as: 1) validity period and special conditions for storage or 2) package recyclability.

Table no. 5: Total Variance Explained

\begin{tabular}{|c|c|c|c|c|c|c|}
\hline \multirow{3}{*}{ Components } & \multicolumn{3}{|c|}{ Initial Eigenvalues } & \multicolumn{3}{c|}{$\begin{array}{c}\text { Extraction Sums of Squared } \\
\text { Loadings }\end{array}$} \\
\cline { 2 - 7 } & Total & $\begin{array}{c}\text { \% of } \\
\text { Variance }\end{array}$ & $\begin{array}{c}\text { Cumulative } \\
\text { \% }\end{array}$ & Total & $\begin{array}{c}\text { \% of } \\
\text { Variance }\end{array}$ & $\begin{array}{c}\text { Cumulative } \\
\text { \% }\end{array}$ \\
\hline $\mathbf{1}$ & 3.928 & 39.285 & 39.285 & 3.928 & 39.285 & 39.285 \\
\hline $\mathbf{2}$ & 1.099 & 10.991 & 50.275 & 1.099 & 10.991 & 50.275 \\
\hline $\mathbf{3}$ & 1.063 & 10.633 & 60.908 & 1.063 & 10.633 & 60.908 \\
\hline
\end{tabular}

Note: Extraction Method: Principal Component Analysis

Explanations: $1=$ List of ingredients, $2=$ Any ingredient or any technological adjuvant that might cause allergies or intolerance, $3=$ The quantity of certain ingredients or categories of ingredients 
Table no. 6: Component Matrix

\begin{tabular}{|c|c|c|c|}
\hline Components & 1 & 2 & 3 \\
\hline Packaging is recyclable & 0.695 & & \\
\hline Country of origin or place of provenance & 0.676 & & \\
\hline Special storage conditions and/or conditions of use & 0.661 & & \\
\hline Name and address of the food sector operator & 0.658 & & \\
\hline The quantity of certain ingredients or categories of ingredients & & 0.704 & \\
\hline List of ingredients & & 0.845 & \\
\hline Net quantity of food product & & 0.510 & \\
\hline $\begin{array}{l}\text { Any ingredient or any technological adjuvant that might cause allergies } \\
\text { or intolerance }\end{array}$ & & 0.532 & \\
\hline Special storage conditions and/or conditions of use & & & 0.736 \\
\hline Minimum validity date or expiration date & & & 0.857 \\
\hline
\end{tabular}

Note: Extraction Method: Principal Component Analysis.

Explanations: 1= List of ingredients, 2=Any ingredient or any technological adjuvant that might cause allergies or intolerance, $3=$ The quantity of certain ingredients or categories of ingredients.

To test the hypothesis, only the first factor was used in the analysis, which explains approximately $40 \%$ of the data variance. In order to test the differences between mean scores of this factor, the normality of the distribution using a Shapiro-Wilk was tested (Cramer and Howitt, 2010). The statistic value is 0.981 , which corresponds to significance level sig. <.001. But analysing the Q-Q diagram we noticed the linearity of the distribution which indicates that we have a normal distribution.

As such, was used a paramedic test, T-test for independent samples (Independent Samples T-test), to test the differences between the factor averages at gender population level:

The score of the feminine population is .145 , positive score associated with a higher importance and the one of the masculine subpopulation is -.436, negative score associated to a lower importance (table no. 7). As it results from table no. 8, value $t=5.062$ ( sig. $<.001$ ), aspect that allows us to state that between the two average values there is a significant statistic difference. As such, we reject the null hypothesis and we accept the hypothesis enunciated. Women, unlike men, grant a higher importance to the information that is mandatory on the label.

Table no. 7: Descriptive statistics

\begin{tabular}{|c|c|c|c|c|c|}
\hline & Gender & $\mathbf{N}$ & Mean & Std. Deviation & Std. Error Mean \\
\hline \multirow{2}{*}{$\begin{array}{c}\text { Importance } \\
\text { factor }\end{array}$} & Women & 285 & .1452724 & .92697983 & .05490955 \\
\cline { 2 - 6 } & Men & 95 & -.4358171 & 1.08619262 & .11144101 \\
\hline
\end{tabular}

Table no. 8: T-test for independent samples

\begin{tabular}{|l|c|c|c|c|c|c|c|c|c|c|}
\hline \multirow{2}{*}{} & \multicolumn{2}{|c|}{$\begin{array}{c}\text { Levene's } \\
\text { Test }\end{array}$} & \multicolumn{6}{|c|}{ t-test for Equality of Means } \\
\cline { 3 - 11 } & & F & Sig. & F & Sig. & F & Sig. & F & \multicolumn{2}{|c|}{ 95\% Conf. Int. } \\
\cline { 3 - 11 } & & & & & & & Lower & Lower \\
\hline $\begin{array}{l}\text { Importance } \\
\text { factor }\end{array}$ & $\mathbf{1}$ & .922 & .338 & 5.062 & 378 & .000 & .581 & .115 & .355 & .807 \\
\cline { 2 - 11 } & $\mathbf{2}$ & & & 4.677 & 142.404 & .000 & .581 & .124 & .336 & .827 \\
\hline
\end{tabular}

Note: $1=$ Equal variances assumed, $2=$ Equal variances not assumed 
Our results are similar to those of other authors, and the explanations can be the fact that women are the ones who shop in a larger number than men and are more interested in the physical and health aspect.

- Age

In our study the average age of those who never read the label is approximately 7 years higher than the one of those who read it (table no. 2). Prior studies have shown that young and mature persons read in a higher number the label than the old ones (over 65 years) (Bender and Derby, 1992; Mannell et al, 2007). By crossing the results provided by the level of education and the frequency of reading the label, we notice an association between the two variables. The adjusted residual values are over 2 and the Chi Pearson value has asymptotic significance (2-sided) under 0.05 (table no. 9).

Table no. 9: Adjusted residual values and Chi-Square Tests

\begin{tabular}{|c|c|c|c|c|c|c|}
\hline & \multicolumn{5}{|c|}{ Age } \\
\hline & & \begin{tabular}{|c|}
$18-25$ \\
years old
\end{tabular} & $\begin{array}{c}19-35 \\
\text { years old }\end{array}$ & $\begin{array}{c}36-45 \\
\text { years old }\end{array}$ & $\begin{array}{c}46-65 \\
\text { years old }\end{array}$ & $\begin{array}{c}\text { over } 65 \\
\text { years old }\end{array}$ \\
\hline \multirow{5}{*}{$\begin{array}{l}\text { How often do } \\
\text { you read the } \\
\text { information } \\
\text { on the label? }\end{array}$} & Never & -9 & .7 & -.5 & -.5 & 4.0 \\
\hline & Rarely & 4.5 & -1.0 & -2.9 & -1.5 & .2 \\
\hline & Sometimes & 3.1 & 1.5 & -3.3 & -2.2 & -.5 \\
\hline & Very often & -4.7 & 1.4 & 4.3 & .2 & -1.8 \\
\hline & Always & -1.7 & -3.2 & 1.6 & 4.2 & .9 \\
\hline \multicolumn{7}{|c|}{ Chi-Square Tests } \\
\hline \multirow{2}{*}{\multicolumn{3}{|c|}{ Pearson Chi-Square }} & Value & df & \multicolumn{2}{|c|}{ Asymp. Sig. (2-sided) } \\
\hline & & & 93.940 & 16 & \multicolumn{2}{|r|}{.000} \\
\hline \multicolumn{3}{|c|}{ Likelihood Ratio } & 87.333 & 16 & \multicolumn{2}{|r|}{.000} \\
\hline \multicolumn{3}{|c|}{ Linear-by-Linear Association } & 28.841 & 1 & \multirow{2}{*}{\multicolumn{2}{|c|}{.000}} \\
\hline \multicolumn{3}{|c|}{ N of Valid Cases } & 392 & & & \\
\hline
\end{tabular}

\section{- Education and income}

The data from our study shows that with the number of years spent in formal education, the frequency of reading information on the label increases. By crossing the results given by the level of education and the frequency of reading the information on the label, we observe an association between the two variables. Adjusted residual values are over 2, and the Chi Pearson value has asymptotic significance (2-sided) under 0.05 .

In what concerns the level of education and the income, most studies show that the persons with lower revenue and an inferior level of education will be less interested about the information on the label due to the fact that they don't understand it (Blitstein and Evans, 2006). The results of our study are similar to the ones found in the literature. Thus, based on the percentage gathered, the label is read very rare or never by the respondents that graduated high school, (19.7\%), university, (14.3\%), master studies, $(13.7 \%)$ and doctoral studies $(6.8 \%)$. On the other side, the respondents that read the label very often or always are, in the order of the interest granted: doctoral studies graduates $(65.5 \%)$, master studies graduates $(58.9 \%)$, university graduates $(48.8 \%)$ and high school graduates $(36.1 \%)$. 


\section{- Influence of children under the age of 5 upon the frequency of information by reading the label}

Although no data has been found, at the level of studying the specialty literature, on the existence of differences in the frequency of information for those shopping for children under 5 years of age than those who buy products for children aged 6-18, personal experience shows us this fact. Thus, the hypothesis was formulated: $\mathrm{H}_{2}-$ The persons that buy food for children under the age of 5 read the information on the label in a higher proportion than the ones that buy products for children between the ages of 6-18.

We notice that the ones that state that they read the information on the label very often (using the residue analysis), register significant differences in the case of those that do not shop for children (residual value $=-3.7$ ) and those who shop for children between the ages of 0 and 5 (residual value $=3.5)$. Chi Pearson value $=21.342$ value with asymptotic significance $(2$-sided $)$ 0.011 , indicates the existence of a significant association from the statistics points of view. The results indicate the reject of the null hypothesis and the acceptance of the hypothesis enunciated. The explanations probably start from the maternal care for an as healthy as possible feeding and go to the large number of articles and programs that emphasize the importance of parenting information, such as reading the labels (Lenihan, 2005).

\section{- Smokers versus athletes}

As in other studies (Satia, 2005), less interested about the information on the label are the overweight and the smokers (table no. 2). It looks like neither the status of smoker or athlete doesn't influence the frequency of reading the information on the label. The explanations come from the fact that in our case, most smokers are also graduates of higher education(43.5-college, 21\% master's degree, $9.2 \%$ doctoral studies), and, along with education, the frequency of reading information on the label increases.

\subsection{Perception over the correctness of the information on food labels}

\section{- Perception over the correctness of the information on food labels}

Out of the 392 respondents that have answered to our invitation to fill in a questionnaire, $42.6 \%$ consider the information on the label as real, $28.8 \%$ do not consider it real and $25.5 \%$ don't know or do not answer. $3.1 \%$ are represented by the ones who didn't answer to this question (the ones that never read the information on the label). There is an association between the results of this question and the level of understanding the information on the label. Through residue analysis we notice significant differences between the ones that rarely understand the information on the label and trust the information on the label (residual value=2.0) and the ones that they although rarely understand the information on the label, don't trust these values (residual value $=2.5$ ). Chi Pearson value $=20.659$ with asymptotic significance (2-sided) 0.008 indicates the existence of a significant association from the statistics points of view.

Our results are different than the ones of the study done at EU level that showed that the confidence of Romanians in the information on the food label was 61\% in 2013 (Ipsos and London Economics, 2013). The reasons can be multiple, starting from the disclosures in the media regarding the untruths on the label to the fact that a small percent understands the technical language from the list of ingredients, or the food scandals in the past. 


\section{- The link between label reading frequency and food poisoning}

$28.7 \%$ of the respondents that read the labels of food products have suffered food poisoning due to a product bought and labelled from a store. One of the most common reasons for food poisoning is expired food consumption (Agri-Food and Veterinary Authority, 2015). In order to find out if there is any relation between the frequency of reading and the perception of reality upon the information on the label we made a crossing of the results of the two questions. The results (residual values under 2) indicate the lack of association between the two variables. Respondents to our study do not attach great importance to the expiration date of foods, so it is likely to be based upon the fairness of sellers who are forced to withdraw from trade expired products.

\section{- Trust in food quality, depending on the country of origin}

Most respondents $(56.8 \%)$ prefer local products, $41.4 \%$ products from the EU and $2.1 \%$ products from outside EU or Romania. Over half of the respondents $(52.1 \%)$ consider that the products sold in Romania have an inferior quality than the ones sold in EU. The explanation for the high number of respondents that consider this, is, first of all the numerous press articles that highlight the quality difference between many food products sold under the same name in the East compared to the West of Europe (Scărișoreanu, 2016).

\subsection{Consumer perception on technological benefits in the food sector}

When they were asked about the benefits of technological innovations in the food industry, the majority said that they consider them neutral $(66.1 \%), 25.3 \%$ do not consider them at all beneficial and only $8.7 \%$ consider them beneficial. Using the crosstabs, finding out the residual value and Chi Square tests, we notice a connection between age and the perception upon the benefits brought by technology. Basically, once over the age of 65 , the respondents consider less and less beneficial the technological innovations in the food industry (adjusted residual value $=2.8$ and Chi Pearson value $=10,862$ ). Elders have less confidence in the good intentions of the producers, opposed to the young, aspect proved also by other studies (Worsley, 2003). Another connection noticed is between the family income and the perception upon the benefits of technological innovations. Basically, low incomes (under $3000 \mathrm{RON} / \mathrm{month} /$ family) are correlated with the trust in technological benefits (adjusted residual value $=2.6$, for those with revenue under $1500 \mathrm{RON}$ and 2 for the ones with revenues between 1501 and 3000 RON and Chi Pearson=13.829 value with asymptotic significance (2-sided) 0.086 .

\section{Conclusions}

Young age, the number of years spent in formal education and high income influence the frequency of reading the label. It seems that in this process, the consumers are mostly interested in the list of ingredients, allergens, substances that cause intolerance and also in the quantity of some ingredients or category of ingredients. Women grant a higher importance to the information that is mandatory, by law, on the label, than men. For the first time, a breakdown of consumer perceptions was made, based on the age of children for whom food is purchased. Practically, from this point of view, we can see that most often the labels are read by those who shop for children under the age of 5 , followed by those who shop for children aged 6-18, and finally the least interested in the information on the 
label are those who do not shop for children at all. One possible explanation for this phenomenon may be the fact that the main interest of those who shop for children under the age of 5 is their healthy and as appropriate as possible feeding.

Our results (obtained by primary and secondary data analysis), indicate a decrease in confidence in the information on the label (from 61\% in 2013, in an Ipsos and London Economics, to $42.6 \%$ in our study). The reasons are most likely related to media scandals regarding the inferior quality of products sold in Romania compared to those in the EU, and technical language that is hard to understand for the majority, with no specialized studies. In fact, more than half of the respondents consider that products marketed in Romania are of a lower quality than those marketed in the EU. Thus, we notice that a confidence decrease in the information on the label may lead (according to the secondary data sources) to a decrease in the frequency of reading information on the label and, ultimately, may adversely affect consumer health.

An important element in informing consumers is the perception of technological benefits in the food sector. The elders and those with high incomes are the least confident in the benefits of the technological innovations.

The limits of our research are correlated with the lack of financial resources needed to access some studies (privately made and owned) and promoting the questionnaires. Our study could have taken into account other factors such as the perception of the benefits of technological innovations in the food sector, broken down into certain categories (for example, genetically modified food or feeding the animals raised for meat). Being aware of and assuming the above limits, we propose to continue the research, basically moving from a pilot exploratory research carried out on the inhabitants of the Cluj-Napoca metropolitan area, to a national research. Such a study will also take into account other factors as the traditions of the area, preferences in choosing the place to purchase food and the benefits of technology in the food industry, showing the existence or absence of differences between the regions of the country.

The results of this study are useful to companies and institutions dealing with food safety. These, through specially created programs (just as they exist in other countries, for those who are not informed, in our case talking about men, elderly people and those without formal education), can improve the reading frequency and confidence in the information on the label. We emphasize that informing consumers can not be successful if they do not read or trust the information found on the labels.

\section{References}

Agri-Food and Veterinary Authority, 2015. Reading Food Labels The Complete Guide. [pdf] Available at: <https://www.healthhub.sg/sites/assets/Assets/PDFs/HPB/Foo d/FINAL\%20Food_label_brochure_English-pr-E.pdf> [Accessed 11 August 2017].

Alsaddah, A., 2014. How does knowledge and utilization of nutrition labels differ among international and non-international college students. A thesis submitted to the Kent State University College of Education, Health, and Human Services. [online] Available at: <https://etd.ohiolink.edu/!etd.send_file?accession=kent141591402 8\&dispos ition=inline $>$ [Accessed 10 August 2017]. 
Batrinou, A.M., Spiliotis, V. and Sakellaris, G., 2008. Acceptability of genetically modified maize by young people. British Food Journal, 110(3), pp.250-259.

Bender, M.M. and Derby, B.M., 1992. Prevalence of reading nutrition and ingredient information on food labels among adult Americans: 1982-1988. Journal of Nutrition Education, 24(6), pp.292-297.

Bildtgard, T., 2008. Trust in food in modern and late-modern societies. Social Science Information, 47(1), pp.99-128.

Blitstein, J.L. and Evans, W.D., 2006. Use of nutrition facts panels among adults who make household food purchasing decisions. Journal of Nutrition Education and Behavior, 38(6), pp.360-364.

Bosman, M. J., Van der Merwe, D., Ellis, S. M., Jerling, J. C. and Badham, J., 2014. South African adult metropolitan consumers' opinions and use of health information on food labels. British Food Journal, 116(1), pp.30-43.

Brand, A. and Ellerton, A., 1989. Report on Hormone Treated Meat. Brussels: Club de Bruxelles.

Caswell, J.A. and Joseph, S., 2008. Consumer demand for quality: major determinant for agricultural and food trade in the future? Journal of International Agricultural Trade and Development, 4(1), pp.99-116.

Cleeland, B., 2009. The Bovine Spongiform Encephalopathy (BSE) Epidemic in the United Kingdom, International Risk Governance Council. [pdf] Available at: <http://irgc.org/wp-content/uploads/2012/04/BSE_full_case_study_web1.pdf> [Accessed 24 August 2017].

Ipsos and London Economics Consortium, 2013. Consumer market Study on the functioning of voluntary food labelling schemes for consumers in the European Union EAHC/FWC/2012/8604. [pdf] Available at: <http://ec.europa.eu/consumer s/consumer_evidence/market_studies/food_labelling/docs/final_report_food_labelling_ scheme_full_en.pdf>[Accessed 10 August 2017].

Cramer, D. and Howitt, D., 2010. Introducere în SPSS pentru psihologie. Versiunea 16. 2nd ed. Iași: Polirom.

Dabija, D.C. and Băbuț, R., 2013. An approach to sustainable development from tourists` perspective. Empirical evidence in Romania. Amfiteatru Economic, 15(7), pp.439-455.

Ekici, A., 2004. Consumer trust and distrust in the food system: some implications for the debates on food biotechnologies. In: B.E. Kahn and M.F. Luce (Eds.). Advances in Consumer Research. Association for Consumer Research. pp.555-563. [online] Available at: <http://www.acrwebsite.org/volumes/v31/acr_vol31_134.pdf> [Accessed 11 August 2017].

EuroCommerce \& FoodDrinkEurope, 2011. Ghidul privind informarea consumatorilor $\mathrm{cu}$ privire la produsele alimentare (Regulamentul CE 1169/2011). [pdf] Available at: <http://www.anpc.gov.ro/anpcftp/interes_public/ghid_150226.pdf> [Accessed 25 August 2017].

Food Safety, 2009. A Research Study into Consumers' Attitudes to Food Labelling. [online] Available at: <https://webcache.googleusercontent.com/search?q=cache:w 7K2LKutI9EJ: https://www.fsai.ie/WorkArea/DownloadAsset.aspx\%3Fid\%3D8900+\&cd=1\&hl=ro\&c $\mathrm{t}=\mathrm{clnk} \& \mathrm{gl}=\mathrm{ro}>$ [Accessed 27 August 2017]. 
FSANZ, 2008. Consumer Attitudes Survey 2007: A Benchmark Survey of Consumers' Attitudes to Food Issues. Food Standards Australia New Zealand. [online] Available at: $<$ https://www.foodstandards.gov.au/publications/documents/Consumer\%20Attit udes\%20Survey.pdf > [Accessed 10 August 2017].

GAIN Report, 2002. Germany Organic Products Nitrofen Found in Organic Livestock Products and Feeds. [pdf] Available at: <https://apps.fas.usda.gov/gainfiles/200206 /145683789.pdf> [Accessed 4 September 2017].

Garretson, J.A. and Burton, S., 2000. Effects of nutrition facts panel values, nutrition claims, and health claims on consumer attitudes, perceptions of disease-related risks, and trust. Journal of Public Policy \& Marketing, 19(2), pp.213-227.

Gorton, D., Mhurchu, C., Chen, M.H. and Dixon, R., 2009. Nutrition labels: a survey of use, understanding and preferences among ethnically diverse shoppers in New Zealand. Public Health Nutrition, 12(9), pp.1359-1365.

Gracia, A. and Magistris, T., 2016. Consumer preferences for food labeling: What ranks first? Food Control, 61, pp.39-46.

Hair, J., Anderson, R.E., Tatham, R.L. and Black, W.C., 1995. Multivariate data analysis. 4th ed. New Jersey: Prentice-Hall Inc.

Harper, L., Souta, P., Ince, J. and Mckenzie, J., 2007. Food Labelling Consumer Research: what Consumers Want. A Literature Review. Food Standards Agency, [online] Available at: <https://pdfs.semanticscholar.org/6b59/07573ef98a02e41010592e 7853bbeb015cb6.pdf> [Accessed 2 August 2017].

Kristal, A. R., Levy, L., Patterson, R.E., Li, S.S. and White, E., 1998. Trends in food label use associated with new nutrition labeling regulations. American Journal of Public Health, 88(8) pp.1212-1215.

Lenihan, B., 2005. Food and Nutrition Guidelines for Pre-School Services. [online] Available at: <http://health.gov.ie/wp-content/uploads/2014/03/Food-and-NutritionGuidelines-for-Pre-School-Services.pdf $>$ [Accessed 2 December 2017].

Lewis, J. and Weigert, A., 1985. Trust as a social reality. Social Forces, 63(4), pp.967-985

Liakopoulos, M. and Schroeder, D., 2003. Trust and functional foods. New products, old issues. Poiesis and praxis, 2(1), pp.41-52.

Liljander, V., Polsa, P. and van Riel, A., 2009. Modeling consumer responses to an apparel store brand: Store image as a risk reducer. Journal of Retailing and Consumer Services, 16(4), pp.281-290.

Mannell, A., Brevard, P., Nayga, R.Jr., Combris, P., Lee, R. and Gloeckner, J., 2006. French consumers' use of nutrition labels. Nutrition \& Food Science, 36(4), pp.159-168.

McCluskey, J. J. and Loureiro, M., 2003. Consumer preferences and willingness to pay for food labeling: a discussion of empirical studies. Journal of Food Distribution Research, 34(3), pp.95-102.

Meyer, S.B., Coveney, J., Henderson, J., Ward, P.R. and Taylor, A.W., 2012. Reconnecting Australian consumers and producers: identifying problems of distrust. Food Policy 37(6), pp.634-640.

Moorman, C., 1996. A Quasi Experiment to Assess the Consumer and Informational Determinants of Nutrition Information Processing Activities: The Case of the Nutrition Labeling and Education Act. Journal of Public Policy and Marketing, 15(1), pp.28-44. 
Moorman, R.M.Jr., Lipinski, D. and Savur, N., 1998. Consumers' use of nutritional labels while food shopping and at home. Journal of Consumer Affairs, 32, pp.106-120.

Peters-Texeira, A. and Badrie N., 2005. Consumers' perception of food packaging in Trinidad, West Indies and its related impact on food choices. International Journal of Consumer Studies, 29, pp.508-514.

Poortinga, W. and Pidgeon, N.F., 2004. Trust, the asymmetry principle, and the role of prior beliefs. Risk Analysis, 24(6), pp.1475-1486.

Rasberry, C.N., Chaney, B.H., Housman, J.M., Misra, R. and Miller P., 2007. Determinants of nutrition label use among college students. American Journal of Health Education, 38(2), pp.76-82.

Riley, M., Bowen, J., Krause, D., Jones, D. and Stonehouse, W., 2016. A survey of consumer attitude towards nutrition and health statements on food labels in South Australia. Foods in Health and Disease, 6(12), pp.809-821.

Roosen, J., 2003. Marketing of Safe Food through Labeling. Journal of Food Distribution Research, 34(3), pp.77-82.

Satia, J.A., Galanko, J.A. and Neuhouser, M.L., 2005. Food nutrition label use is associated with demographic, behavioral, and psychosocial factors and dietary intake among African Americans in North Carolina. Journal of the American Dietetic Association 105(3), pp.392-402.

Scărişoreanu, M., 2016. Aceleaş̧i produse, calitate diferită in Est faţă de Vest. Ce consumă românii şi ce spune Uniunea Europeană. [online] Available at: <http://www.mediafax. ro/economic/exclusiv-aceleasi-produse-calitate-diferita-in-est-fata-de-vest-ce-consumaromanii-si-ce-spune-uniunea-europeana-16031831> [Accessed 18 August 2017].

Smith, S.C., Taylor, J.G. and Stephen, A.M., 2000. Use of food labels and beliefs about diet-disease relationships among university students. Public Health Nutrition, 3(2), pp.175-182.

Soo-Jiuan, T. and Khai-Ling, T., 2007. Antecedents and consequences of skepticism toward health claims: an empirical investigation of Singaporean consumers. Journal of Market Communication, 13(1), pp.59-82.

Stenmarck, Å., Jensen, C., Quested, T. and Moates, G., 2016. Estimates of European food waste levels. [online] Available at: <http://www.eufusions.org/phocadownload/ Publications/Estimates $\% 20$ of\%20European $\% 20$ food\%20waste\%20levels.pdf> [Accessed 28 August 2017].

Svederberg, E. and Wendin, K., 2011. Swedish consumers' cognitive approaches to nutrition claims and health claims. Food \& Nutrition Research, 55(1). [online] Available at: <http://doi.org/10.3402/fnr.v55i0.5929> [Accessed 21 August 2017].

Taylor, A.W., Coveney, J., Ward, P.R., Dal Grande, E., Mamerow, L., Henderson J. and Meyer, S.B., 2012. The Australian Food and Trust Survey: Demographic indicators associated with food safety and quality concerns. Food Control, 25(2), pp.476-483.

Taylor, E., Meyer, S. B., Coveney, J., Webb, T. and Wilson, A.M., 2016. The process of making trust related judgements through interaction with food labelling. Food Policy, 63, pp.1-11. 
The European Food Information Council - EUFIC, 2017. Global Update on Nutrition Labelling. [online] Available at: <http:/ /www.eufic.org/images/uploads/files/GUNL2017-exsummary.pdf> [Accessed 4 September 2017].

Tonkin, E., Meyer, S. B., Coveney, J., Webb, T. and Wilson, A.M., 2016. The process of making trust related judgements through interaction with food labelling. Food Policy, 63, pp.1-11.

Wongprawmas, R. and Canavari, M., 2017. Consumers' willingness-to-pay for food safety labels in an emerging market: The case of fresh produce in Thailand. Food Policy, 69, pp.25-34.

World Health Organization, 2003. Obesity and overweight. Geneva: World Health Organization. [online] Available at: <http://www.who.int/dietphysicalactivity /media/en/ gsfsobesity.pdf $>$ [Accessed 11 August 2017].

Worsley, A., 2003. Consumers' personal values and sources of nutrition information. Ecology of Food and Nutrition, 42(2), pp.129-151.

Zadek, S., Lingayah, S., and Forstater, M., 1998. Social Labels: Tools for Ethical Trade. [online] Available at: <http://zadek.net/wp-content/uploads/2011/04/New-Econo micsFoundation_Social-Labels_Tools-for-Ethical-Trade_1998.pdf $>$ [Accessed 25 August 2017]. 